\title{
Deep transformation toward decoloniality in social work: themes for change in a social work higher education program.
}

HARMS SMITH, L. and RASOOL, S. 
DEEP TRANSFORMATION TOWARDS DECOLONIALITY IN SOCIAL WORK: THEMES FOR CHANGE IN A SOCIAL WORK EDUCATION PROGRAMME

LINDA HARMS SMITH (Corresponding Author)

Orcid ID: https://orcid.org/0000-0003-4686-0906

Researchgate: https://www.researchgate.net/profile/Linda Harms Smith

Affiliation: Robert Gordon University, Aberdeen Scotland and Research Associate, University of Johannesburg, South Africa. Email: I.h.smith@rgu.ac.uk

SHAHANA RASOOL (Corresponding author)

Acadmic.edu: https://johannesburg.academia.edu/ShahanaRasool

Google scholar: https://scholar.google.co.za/citations?hl=en\&user=AUKm8rsAAAAJ

Affiliation: University of Johannesburg, South Africa

Email:shahanar@uj.ac.za

\section{ABSTRACT}

This paper describes thematic outcomes of a process of engagement around deep transformation towards Decoloniality in a university social work education programme. Given the gravity of working towards Decoloniality for social work education in South Africa, it was critical to theorise about this process. Current South African realities evidence ongoing structures of Coloniality and Apartheid which permeate all spheres, not least the domains of knowledge, power and relationships in higher education.

However, a narrow interpretation of Decoloniality relating only to 'curriculum' or 'indigeneity' as potential for change, is problematic. Ignoring material realities of ongoing Coloniality perpetuates the very oppressive structures it seeks to overcome and so depth transformation which engages with all levels of a social work education programme is required.

This paper engages with thematic areas that emerged and which shaped such work towards Decoloniality, among social work educators. These included domains for engagement with Decoloniality (theorists; pedagogy; educators; learners; content; research and discourse; context) and principles for such work (Afrika as the centre; attention to power dynamics; race, class and gender; acknowledgement of structural issues; critical conscientisation and voice; Ubuntu). These thematic areas now form the basis of the new social work programme at the University.

KEY WORDS: Decoloniality; Social work higher education; Deep transformation; South Africa

\section{INTRODUCTION}

This paper describes thematic outcomes of a process of engagement around deep transformation towards Decoloniality in a university social work education programme. Given the significance and weight of the process of working towards Decoloniality for those involved and for social work education in South Africa, it was critical to theorise about the process and its implications, as t Mamdani (2011) argues: "If we are to treat every experience with intellectual dignity, then we must treat it as the basis for theorisation". Current South African realities 
evidence the presence of ongoing structures of Coloniality and Apartheid (Sewpaul, 2016; Ndlovu-Gatsheni, 2018) which permeate all spheres, not least the domains of knowledge, power and relationships in higher education. In the South Africa context of extreme and ongoing class, gender and race-based inequality, the colonial is said to exist within the "underlying structures of oppression and injustice" (Heleta, 2016, p. 1).

While working towards Decoloniality is an imperative, a more narrow interpretation as it relates to 'Decoloniality of a curriculum' as a potential for change, is problematic. There is a risk that focussing on epistemic Decoloniality alone while ignoring the material realities of ongoing Coloniality in all spheres leads to the perpetuation of the the very structures of oppression and injustice mentioned earlier (Patel Lisa 2014). Holding this tension during work towards Decoloniality, especially in the context of South African social work, will allow for a more productive engagement so that the broader imperative retains the predominant focus of attention - that is, working towards a socially just and equal society in South Africa. The contention in this paper is that the process of working towards Decoloniality in the social work education system is a critical basis for training social workers. These students are required not to reproduce systemic inequalities, but to become agents of social change to attain social, economic and cultural justice for communities.

In this paper, the specific unfolding process of working towards Decoloniality through participatory action research in a particular social work programme is not being discussed, as this has been explained in detail in Rasool and Harms-Smith (2020). This paper rather engages with those key thematic areas that emerged during the process and which in turn through reflexivity, contributed to shaping the process. Thematic areas were identified as domains for engagement with Decoloniality work (theorists; pedagogy; educators; learners; content; research and discourse; context) and principles which should form the basis for such work (Afrika as the centre; attention to power dynamics; race, class and gender; acknowledgement of structural issues; critical conscientisation and voice; Ubuntu). These thematic areas now form the basis of the new social work programme at the University.

\section{ONGOING COLONIALITY}

South Africa's political liberation from colonialism and its extension, Apartheid, resulted in little more than compromised hope. The historic and ongoing legacies of mercantile racist capitalism together with more recent neo-liberal economic policies relying on the free-market as a template for solutions to social problems (Sewpaul, 2016), has led to the continuation of racestratified inequality; ongoing class, race and gender oppression and persistent Coloniality in structures and systems at at all levels of society.

These ongoing colonial structures are similarly reflected in global Coloniality evident in both the geo-political context (Ndlovu-Gatsheni, 2015; Trafford, 2019) as well as in the ecologically, natural world (Mignolo, 2007). Coloniality is said to survive colonialism and refers to "longstanding patterns of power that emerged as a result of colonialism, but that define culture, labour, intersubjective relations, and knowledge production well beyond the strict limits of colonial administrations." (Maldonado-Torres, 2007, p. 243). In the South African context, structures of Coloniality and Apartheid find extended expression (Grosfugel, 2011, Ndlovu- 
Gatsheni, 2018) at levels of material every-day living, ubiquitous power asymmetries, and interpersonal and intra-psychic lived realities. In spite of the impressive political transition from Apartheid in the early 1990s. Materially South Africa is currently positioned as the most unequal country in the world (World Bank, 2018), with race and gender based levels of extreme poverty affecting $55 \%$ of the population (Statistics South Africa, 2018).

The ongoing internalised oppressions and dehumanisation of historic colonial and Apartheid racism (Cesaire, 1955; Fanon, 1970; Biko, 1979) are further evidenced by the ongoing conditions of subalternaity for many (Spivak, 1988). That Coloniality is inscribed at the broadest range of experience is clear, and as such is described in various ways as the Coloniality of being (Maldonado-Torres, 2007), the Coloniality of power (Mignolo, 2000) and the Coloniality of knowledge (Quijano 2007). The damage wrought by processes of appropriation of culture and language is referred to as colonisation of the mind (Hook, 2004; Wa Thiongo, 1980; Biko, 1979). It is argued that in colonial power relations, the "most important area of domination was the mental universe of the colonised, the control, through culture, of how people perceived themselves and their relationship to the world" (Wa Thiongo, 1986, cited in Rivkin and Ryan, 2004, 1135).

It is in this area of 'Colonisation of the mind' deeply embedded in the way structures and systems operate, that this project was developed to work at epistemic Decoloniality with respect to the social work programme where both the authors live.

\section{HIGHER EDUCATION: ONGOING COLONIALITY AND INSTITUTIONAL RACISM}

In South African society generally but also in the academy, colonial relations of domination are re-inscribed through institutional racism, classism and sexism (Duncan, Stevens and Bowman, 2004; Heleta, 2016) and through universalising postulations of the bourgeois, white, European male ideal (Hook, 2004).

The "European intellectual scholarly axis" positioned Europe as the centre of the intellectual universe, providing all the definitions and interpretations of the world according to that experience of history (Wa Thiongo, 1986 cited by Rivkin and Ryan, 2004, 1137), negating, silencing and marginalising other world views and histories. Spivak (1988) describes this Eurocentric and Western domination and subjugation of former colonial subjects through knowledge systems, as epistemic violence. Such hegemonic power and discourses of liberal post-colonial higher education institutions are ongoing and still indicted with lack of transformation and reliance on Eurocentric, Judeo-Christian curriculum content (South African Government, Department of Education, 2008; HESA, 2014).

Heleta (2016) argues that efforts at transformation in the higher education sector have resulted in little change, evidenced by the existence of:

○ 'white', male dominance of scholarship and management;

ongoing foregrounding of Western discourse and knowledges;

○ racially divided campuses

○ privileging of 'white' dominance, 'black' marginalisation 
- untransformed curricula (Repeated government reports on Transformation of Higher education),

- neo-liberal capitalist economic policies of outsourcing of support services

○ increasing universities' financial struggles (South African Department of Education, 2008; Heleta, 2016)

These problems of ongoing coloniality in higher education relate to "issues of institutional and academic cultures, and largely ignored epistemological and ontological issues associated with learning and teaching, curriculum development and pedagogical practice" (HESA, 2014). These underlying structural and institutional systems and approaches have contributed to a managerialist rather than transformative space of academic engagement and intellectual freedom and questioning in the higher education context.

Epistemic coloniality through the destruction of African knowledge systems, culture and language (Wa'Thiongo, 1986) are manifest in formalised education systems. In this way, higher education in South Africa is not only subjected to ongoing Coloniality, it may also be described as itself, a mechanism of colonisation. For example, it was described by the Department of Higher Education and Training as continuing to reproduce gender, class, race and other inequalities with respect to access to educational opportunities and success (DHET, 2012). Nyamnjolah (201 p. 69) argues that more broadly, "education in Africa is still the victim of a resilient colonial and colonising epistemology". However, emphasising epistemological coloniality in higher education, neglects the broader conceptualisation which includes the Coloniality of being and power (Mignolo, 2007). This results according to Nyamnjolah, in the inferiorisation and devaluation of African value systems, creativity and agency described as "a culture of dependency championed by whitening up as an eternal pursuit" $(2019$, p. 71$)$.

It was a growing consciousness around these truths that South African students began to demonstrate their frustration and rejection of colonial education through the Rhodes must fall and fees must fall movements (Langa, 2017; Author and another, 2018). In spite of this, demands for the engagement with processes of Decoloniality are derided, as may be seen in the conservative approach by some South African universities' vice-chancellors., and the immediate de-emphasis on strategic approaches to addressing decoloniality once the students stop protesting. Jansen (2017), declared his scepticism towards demands for decolonisation and "reducing student concerns around curriculum to 'flag waving' and institutional responses to review curriculum in the light of such concerns to 'regrettable bowing and scraping'" (Trowler, 2018, p. 133).

\section{SOCIAL WORK: PARADOX OF COLONIALITY AND HOPE}

In ways similar to the struggles of higher education generally, the historiography of the discipline of Social Work in South Africa is a project of racist capitalism and the 'poor white question' (Author, 2014). Social work became formalised through university education fully imbricated in Apartheid ideology as conceived by its first Head of School of Sociology and Social Work, Verwoerd, at the University of Stellenbosch in 1933. While some of the Apartheid knowledge and discourses became obsolete, and other were challenged Apartheid practices during the 
years of struggle for liberation in South Africa, social work in higher education has struggled to achieve transformation from its Eurocentric and colonial legacy. In spite of many social workers pursuing a radical and transformational agenda, social work practitioners are often still agents of social control and status quo maintenance with social work failing to become a profession of transformative social justice. It may be argued that tension still exists in its positioning on a continuum of knowledge and discourse from domesticating and colonising to liberatory and transforming (Author, 2014).

However, the more recent moves towards interrogating and disrupting Coloniality in the higher education sector generally, and in the Social Work Education sector more specifically, are indicative of the urgency around deep transformation. Social work is well placed to engage with these issues, drawing on a complex history of both oppressive and domesticating, as well as radical and liberatory practice. The role that social workers in South Africa play at all levels of society, means that they are well placed to engage with anti-oppressive, transformational and anti-colonial practice.

If Decoloniality then, in the South African context, is about both a disruption of the epistemic violence of Eurocentric domination as well about bringing about social change, then the education of social work students should be regarded as critical. Social work students enter the academy where such epistemic violence of coloniality is perpetuated, and therefore their own internalised oppression rooted in the broader South African context becomes further entrenched. This internalised oppression and their subjectivities are to be "understood within the context of structural issues through which the individual mediates his/her lived experiences" (Kiguwa, 2014, 69). It is critical therefore, that together with a process of working towards Decoloniality, conscious efforts are made to disrupt coloniality in all its guises at all levels of society. It is the pedagogy of hope which provides the impetus for such work (hooks, 2003)

\section{SOCIAL WORK EDUCATION TRANSFORMATION AT A PARTICULAR UNIVERSITY}

\section{Theorising Decoloniality and approaching this project}

There is a risk that Decoloniality as a concept remains at an abstract level lacking materiality (Patel [Lisa], 2014). When considering that the nature of 'settler colonialism' was the appropriation of land, resources (reference ) and the establishment of superiority and normalisation of 'whiteness' and the psycho-political subjugation (Fanon, 1967; Tuck and Yang, 2012), the basis of decolonization must be material changes in economic relations and land ownership. Without these changes, abstract and 'academic' notions of Decoloniality risk maintaining the status quo and relationships of coloniality. According to Tuck and Yang (2012, p. 3), the easy enactment of decolonial discourses are "a series of moves to innocence, which problematically attempt to reconcile settler guilt and complicity" and absolve those holding hegemonic power.

We argue that appropriating Decoloniality as a concept which relates only to revision and 'indigenisation' of the curriculum, risks re-inscribing unequal power relationships. 'White' privilege is easily maintained where efforts towards Decoloniality are deemed 'successful and completed' while the attendant power relationships, status hierarchies, and patterns of knowledge and resource ownership remain unaltered. In particular, the historically privileged 
and powerful position of 'white' social work academics must be carefully scrutinised and acknowledged. These ongoing asymmetrical power relationships mean that there are advantages of easier access to resources and social capital, in a South African context which still privileges those who are 'white' and male (Heleta, 2016). Hence, it is acknowledged here, that whilst the process for working towards Decoloniality of the curriculum was transformative, it has not at the core changed power relationships of the material conditions of students or previously marginalised staff members.

Nevertheless, a number of theoretical perspectives were used in conceptualising this work of Decoloniality and transformation in a social work education programme (Bulhan, 1980: Freire, 1972; Fanon, 1968; Biko, 1978; hooks, 1991; Quijano, 2007; Ndlovu-Gatsheni, 2018). Different theories were utilised to inform different aspects of the process. For example, Bulhan's (1980) theorising around processes of change in conditions of colonialism and racism (Bulhan, 1980, p.105) was utilised to explore how "Capitulation to the dominant culture characterised by a capitalist ethos, elitism and an inferiority complex, Revitalization of the indigenous culture with rumination of identity and race consciousness, and Radicalization with components of classconsciousness and socialist ethos synthesised arriving at a commitment to transformation and radical change". The work of Fanon (1968) was critical to considering both the intrapsychic and the political. Whilst, Biko's (1978) dialectical arguments around black consciousness and black solidarity as the antithesis to the thesis of white racism was critical for considering the locationality of all participants and dealing with issues of race in the South African context. To consider issues of race and intersections, hooks' (1991) black feminist understandings of the power of marginality as a place for radical resistance and the production of counter-hegemonic discourse was influential. In addition, understandings of Decoloniality of power, being and knowledge (Quijano, 2007; Maldonado-Torres, 2017); critical conscientisation and praxis (Freire, 1972) underlie the approach and philosophy of the process. Finally, by considering epistemic Decoloniality (Ndlovu-Gatsheni, 2018) it allowed us to develop an approach and intervention around transformation of a social work programme towards Decoloniality.

\section{Background}

It could perhaps be argued that the necessity for a different programme of education in South African social work has existed from its inception - when it was conceived of as a discipline of eugenics, as a means of social hygiene (Author, 2014), as the promotion of a racialised hierarchy of wellbeing, and of 'White' flourishing. The prohibition of any formal Anti-apartheid texts meant that liberatory social work discourse remained in the less formal domain, neglecting to create awareness of the critical and radical contributions of many social workers that played a leadership role in the anti-Apartheid struggle such as Winnie Mandela, Ellen Kuzwayo, Leila Patel (amongst others). In addition, social workers drove anti-Apartheid activities through various organisations such as SABSWA (South African Black Social Workers Association and The Concerned Social Workers Movement. Similarly, social work educators also stand out as role models and luminaries of progressive resistance, change and transformation, including for example Adam Small, Lionel Louw, Anne Letsebe (Allie, 2019; South African History online, 2019)

Nevertheless, within formal systems, it was among the countries neighbouring South Africa that a more anti-colonial discourse emerged in relation to social work in the 1990s, notably in the 
Journal of Social development in Africa (Kaseke, 1991; Osei-Hwedi, 1993; Bar-On, 1999). It was however with the end of Apartheid that a more formalised expression of the need for transformation was expressed both in the welfare and the social work education sector (Hochfeld, 2009).

This started with the change in the South African Welfare system to a developmental approach with the White paper for social welfare that was introduced in 1997. As progressive as the Developmental Welfare approach to social work is, in comparative to previous approaches, it still did not directly address issues of power and deep seated coloniality, racism, sexism and classism. The need for post-colonial social work and decolonisation of knowledge became more explicitly articulated (Sewpaul, 2006; Author, 2008) post the \#FeesmustFall movement. As a response, social work academics in South Africa through the Association of South African Social Work Educational Institutions (2017) held a conference on Decolonising the Social Work Curriculum. It was in the context of these broader processes that this particular work on a declared process of social work curriculum transformation and Decoloniality was initiated. In fact, it was at this conference that the authors of this paper, agreed upon the need for a process of interrogation, critical reflection and engagement with a specific social work programme, to consider how social work education could be transformed.

\section{Research methods}

As stated earlier, this paper focusses on the thematic areas as outcomes of the process of work towards Decoloniality rather than the detail of the research process. The research approach and methods are discussed elsewhere (Rasool and Harms-Smith, 2020). Of importance, is that we utilised a collective, collaborative approach from the inception of the project. Particular care was taken in attending to the composition of the workshop facilitating team, to address issues of hegemony and power, as well as the decision making around the research process. $A$ collaborative approach was adopted from the inception, using a critical participatory action research approach, which incorporated aspects such as those described by Denzin $(2017$, p. 8) as "critical embodied, transformative, dialogic, reflexive, participatory, emancipatory, narratives of resistance, affect ... and praxis" as a means of working towards Decoloniality.

All of those involved in the social work programme participated in the conceptualisation of the project and the way in which it would form the basis of a research study. It was important that we foregrounded rather than denied, the unequal power relationships of oppression, privilege, inequality, silence, and 'voice' amongst those participating in the process. It was also critical that as one of the facilitators of the process as an author of this paper my positionality as a privileged 'white' South African was acknowledged, to make conscious and thus attempting to resist, its associated power, during the process of engagement.

The processes of reflection, dialogue and debate, through individual and collective engagement in individual meetings, workshops and group discussions, produced rich data. This was collected and shared through equal access to a shared drive, by the team of participants and thematically analysed and then utilised in a process of praxis which incorporated a number of reflections, analyses and applications, followed by further reflections (Freire, 1972). 
The outcomes of the process of engagement over the period of eighteen months, were conceptualised as domains by which to critically reflect, interrogate, and take action, based on a number of guiding principles. The analysis of themes arising in this way is presented on the form of a template for engagement and utilisation in processes of working towards Decoloniality. The content of the various themes were expressed as existing in various domains of praxis as well as through foundational principles identified as critical for ongoing work towards Decoloniality. The overall process as well as the outcomes described, hold potential for use in other contexts of social work education as well as in social work practice more generally.

\section{FIGURE: WORKING TOWARDS DECOLONIALITY}

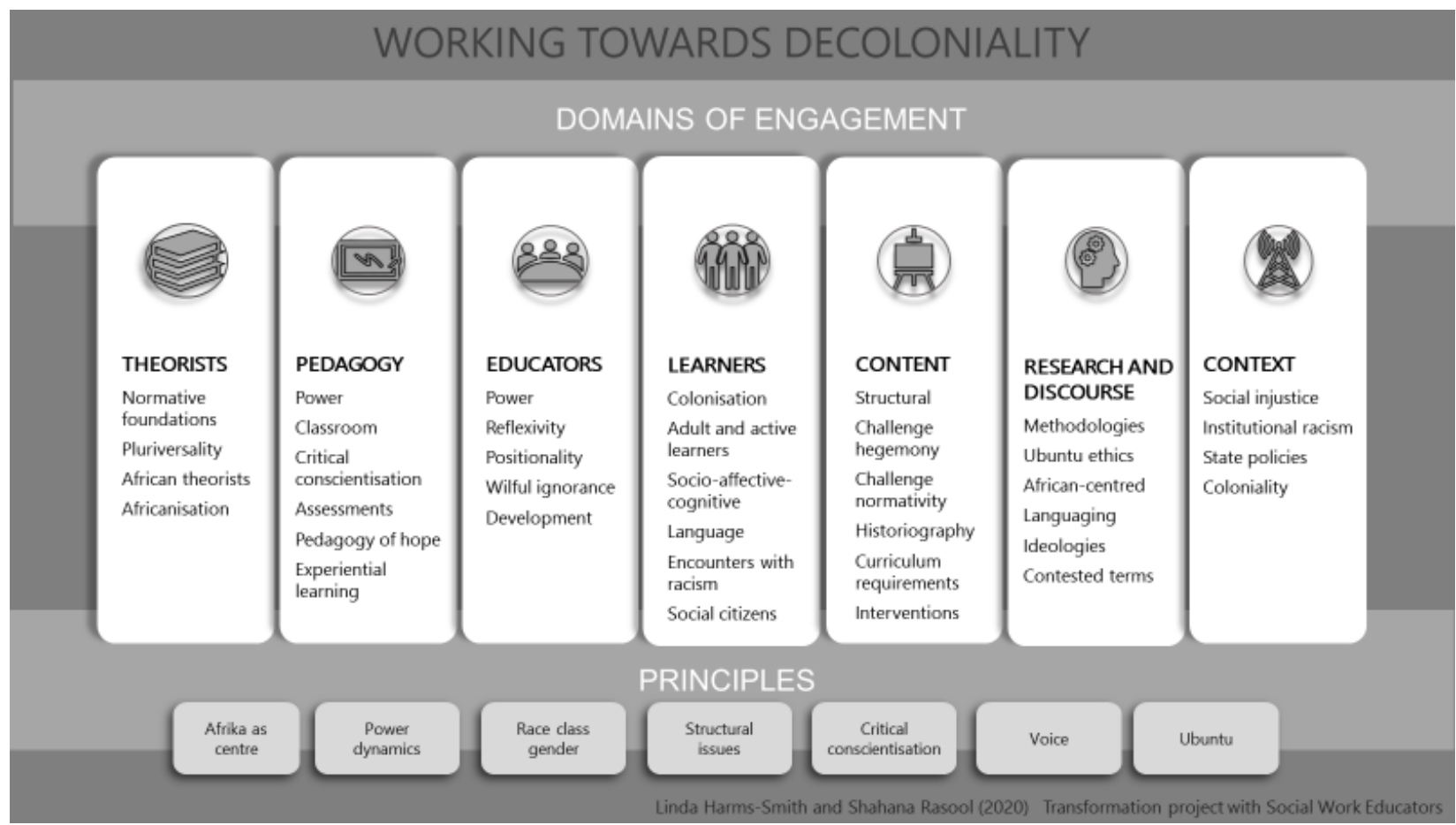

\section{DOMAINS}

It was evident in the engagement with the work towards decoloniality, that this had and would need to occur in various domains. It was futile to work only in relation to the curriculum as Coloniality is implicated in far more than only the area of curriculum content. Work towards Decoloniality must therefore occur in all domains namely: inclusion of theorists; pedagogical practices; educators themselves; learners; content; research and discourse; and the broader context. These domains which require the praxis of critical reflection, interrogation, action and further reflection (Freire, 1972), are elaborated below.

\section{Inclusion of theorists}

Theories are critical in informing both knowledge production and practice. Hence, when selecting theorists for inclusion in the curriculum, it is important to rethink normative foundations of theory so that theorists more appropriate for the South African context that 
challenge ongoing Coloniality are included. The early approach to work towards Decoloniality started with prioritising the selection of the work of 'black' African theorists given the past (and often still, current) privileging of 'whiteness' and Eurocentricity in the voices that are dominant (Heleta, 2016). However, it is more than utilising the work of Africa and indigenous people, it requires an 'oppositional' and critical reading; and critical interrogation of taken-for-granted texts and theorists. Adopting a stance of Africanisation means that Africa is situated the centre, and other theorists and theories are understood from this position (Comaroff and Comaroff, 2015; Ndolvu-Gatsheni, 2018). This does not mean an exclusion of Northern/Western theorists, but a centering of African theorists and indigenous work, and a critical engagement with Northern/Western approaches from the perspective of African and indigenous work. This requires flipping the script and shifting the gaze; see Rasool (2019) as an example of a chapter that foregrounds African theories.

\section{Pedagogical practices}

In order to overcome and resist power imbalances that students experience in their daily lives in the context of socio-economic inequality, racism, sexism, classism, homophobia and Coloniality (Author, 2008; Bozalek, 2011), there must be an awareness and critical consciousness (Freire, 1972) about such power dynamics among both educators and students in the learning environment (Sakamoto and Pitner, 2005). Hence, the way in which we teach should challenge oppressive structures that reinforce power of educators and disempower students.

Hence, learning should occur through liberatory and humanising education with an emphasis on the co-creation of knowledge. Assessment styles should be developmental and have the purpose of generating knowledge. This should include therefore an ongoing critical engagement with controversial issues in order to contextualise knowledge. A 'pedagogy of hope' should be an underlying theme (Kiguwa, 2017) that allows students to reflect on their histories, current experiences of oppression and alienation in a colonial education system, and brings in indigenous practices and knowledge systems as part of the norm, not as extraordinary and peculiar. as the integration of 'indigenous' ways of learning (Room, 2015), that include more collective learning approaches, storytelling and narrations, co-operative rather than competitive learning activities, and that align better with the students' worldviews should be central to higher education pedagogy.

\section{Educators}

Educators are frequently critical of the process of Decoloniality, since 'Colonisation of the mind' (Fanon 1986) is deeply implicated in the collective education (the second author in particular acknowledges this). Hence, educators ourselves need to interrogate our own positionality with respect to power, racism, 'whiteness', gender, heterosexism, class and other identity categories bearing power, privilege or oppression (Vazquez, 2015). For this, reflexivity and perpetual 'autocritique' is required, with a commitment to a processes of critical conscientisation, central to the initial stages of the process at this university. Educators need to, be willing to act courageously and as stated by Alexander $(2006$, p.7) understand pedagogies as "transgressing, disrupting, displacing, inverting inherited concepts and practices." This all should be modelled and where possible, made available for scrutiny through self-reflection, self-disclosure and 
acknowledgement of personal positionality and complicity. This also requires openness to critique and critical feedback, both from colleagues and students as well as an emotional commitment to an attitude and practice of Decoloniality, in all spheres of life.

\section{Learners as bearers of their context}

It is important to understand the impact of racism, Coloniality and intersections of oppressions on students and their ability to engage critically in higher education spaces Students' struggle with asymmetrical power relationships, socio-economic deprivations; difficult socio-affectivecognitive histories; and categorisations, bring various forms of privilege or oppressions. Further, considering that universities in South Africa use English as the language of instruction, students are disadvantaged both where language is a second or third language, but also as language is a bearer of culture. Students should be helped to explore their own encounters of racism, oppression, privilege and intersectionality and be enabled to become social citizens as well as social workers (Author, 2008; Rohlender et al, 2008; Bozalek, 2011). This is critical if students' voices are to be given prominence and for them to become knowledge producers, and not just consumers.

\section{Curriculum content}

Western hegemonic thought and its normativity has dominated higher education and in particular social work education. These should be critically interrogated and challenged and indigenous knowledges revitalised through the reclaiming of histories, cultural narratives and illustrations, and local helping practices. African social work theorists and pioneers who had been elided from formal texts should be celebrated, specifically to reclaim unwritten and undocumented narratives about the proud tradition of social work contributors and activists for social change. Similarly, curriculum content should aim to achieve learning outcomes which enable full integration of contextualised African world views and cultural practices with global social work discourses (Osei-Hwedi, 1996; Ross, 2008).

Eurocentric and American knowledges and content will be relevant insofar as these relate to the local context. Social work students should be equipped for the challenges of development and wellbeing in the African context (Mupediswa, 1992). The ideologies informing social work curriculum content should be interrogated so that curricula are able reflect commitments to social justice and human rights for all . Furthermore, social work knowledge discourse and practice should always be approached from an historiographical perspective. This means that the unfolding nature of social work can never be seen in a manner which is isolated from the social and political context in which it continue to develop. Such that social workers become agents of social, political, cultural and economic justice, not reinforces of the status quo.

The South African context of Apartheid's racist dehumanisation, means that the curriculum must facilitate substantial learning around 'race' and racism, patriarchy, homophobia, classism and ideologies associated with the hierarchical structuring of South African society (Sewpaul, 2007). However, the curriculum should also be a means towards conscientisation and anti-oppressive practice, include learning outcomes related to colonisation and Decoloniality. It should enable social workers, in their post-qualifying roles to to practice from a position of Decoloniality and anti-oppressive engagement with people and communities with whom they work. 


\section{Knowledge, discourses and research}

Social work discourses have been influenced and shaped by historical racism, individualist ideologies, neo-liberalism and essentialising discourses (Sewpaul, 2007) and so the various ideological underpinnings of social work theories should be critically analysed and challenged. Historically, formal and hegemonic social work knowledge and texts had reproduced or were silent about oppressive socio-political structures which were depicted as natural and inevitable (Gransci, cited by Kincheloe and McLaren, 2000).

African-centric and the many various 'indigenous' knowledges of South African peoples, should form the basis for intellectual engagement (Ndlovu-Gatsheni, 2018), and everything else in relation to these knowledges, not in the reverse as is the current position. These hegemonic knowledges should be interrogated and exposed to critical engagement. Attention should be paid to discourse and languaging, ensuring critical interrogation and contestation of taken-forgranted terms, definitions and understandings. terminologies, where consented-to meanings continue to perpetuate categorisations, stereotypes and oppressive understandings should be challenged. Extensive varieties of textual, visual, art- and media-based sources exist which are able to contribute to social work knowledge and discourse should be embraced and incorporated.

Similarly, research and research methodologies should be empowering, participatory, collective and empowering. Research approaches should be conscious of power dynamics, respectful of African centred ethical considerations and embrace an African-centric relational paradigm as suggested by Chilisa et al (2017). Firm commitment to critical and collective research approaches which collaborate for significant and transformative contributions to those participating is critical. For this reason, renewed effort must be made to explore and develop appropriate ethical principles around collectivism, respect, dignity, participation and transformation.

\section{Context}

Ignoring the realities of a context of inequality, social injustice and ongoing institutional racism, sexism, classism, homophobia and various other intersections of oppression, creates dissonance between lived experience of the South African context and the particular social work knowledge and discourse provided in theoretical interpretations of formal texts. Knowledge, discourse and curriculum content should always be appropriately contextualised within the local social and cultural realities to prevent dissonance between social work students' lived reality and the content to which they are exposed.

An emphasis on the local and regional context should always underpin clinical, individual and therapeutic knowledges. The broader or 'public' context of socio-political factors and historical dynamics will enable a critical and anti-oppressive engagement with peoples' private troubles. In spite of being the second strongest economy in Africa, its market size being ranked $35^{\text {th }}$ in the world, it's health system for example is ranked $125^{\text {th }}$ in the world and South Africa is described as having "the most persistent unemployment rates" currently at 29\% (World Economic Forum, 2019). T A critical engagement with the boarder context is necessary in order to develop critical consciousness about societal dynamics and enable the challenging of the institutional status quo (Reisch and Jani, 2012). This engagement should reflect on the extent to which South African 
remains stratified by 'race', class, gender since it is still one of the most unequal country in the world, with extreme levels of poverty.

\section{PRINCIPLES}

While the various domains of Decoloniality emerged as those areas critically important to be included in work towards Decoloniality of the social work programme a series of priorities were also identified which now form the seven underlying principles of the overarching social work programme

The first principle identified by the group of educators in transforming the social work programme, is that of positioning Afrika as the centre, Social work education ensures that answering all cultural, economic, political, and social questions related to social work theory and practice, occurs from a position centred in Africa (Asante, 1987). Instead of prioritizing and centering European thought, writers, authors, research and ways of thinking, African thought is positioned as the Centre. African perspectives are foregrounded While other perspectives are moved to the periphery and used to support African and indigenous knowledge systems. A consequence of positioning Afrika as the centre means that so called 'Indigenous knowledges', or local knowledge systems, deemed to be specific or unique to particular local cultures or contexts are foregrounded and should not be patronised (Kaya \& Seleti, 2013). 'indigenous' knowledges need to be incorporated, embraced as appropriate in all forms of practice.

The second principle identified, was the necessity to account for power dynamics in structures, systems, and relationships. Accounting for power dynamics is crucial to for understanding and engagement in the South African context with people who are or have been oppressed. The complexities of asymmetrical power relationships, ever-present in dominant and oppressive contexts of inequality, are played out further in the social work relationship. The ongoing legacy of Apartheid and its collective traumatisation and dehumanisation is a reality for most social work students, who then come into alienating and colonial education systems. These ongoing power relationships which perpetuate the status quo, and undermine African and indigenous knowledge systems and knowledge production by students, should be exposed and challenged.

Third, the team considered it critical to confront issues of racism, sexism and classism in race, class and gender as oppressive hierarchies play out as intersections of oppression and disadvantage in South African society. By having a principled critical awareness of various oppressions social work is able to be alert to, for example, not only the feminization of poverty, but also the further multi-dimensional intersection of oppressions suffered by for example 'black' women or other marginalized groups such as people with disabilities, or LGBTQI+ communities.

Fourth, social work practice requires that in dealing with inequality and oppression, it is critical to address structural issues at the core of all our work and recognize that many issues are exacerbated by structural considerations. Foregrounding structural issues implies that a structural perspective should be embraced which argues that problems lie in oppressive and inequitable social structures. In the South African context, oppression and structural disadvantage remain major issues to be addressed. Social structures such as patriarchy, capitalism, institutional racism, and socio-economic inequalities maintain oppression through state enforced institutions and through implicit consent of ordinary people. Through the foregrounding of structural issues, student social workers are able to identify and challenge oppressive structures and power dynamics which maintain racism, sexism, classism (Sakamoto 
and Pitner, 2005). The particular South African context of ongoing structural oppressions therefore emphasises the need for critical conscientisation around issues of social justice and social change and a more politically engaged approach (Mmatli, 2008; Author, 2013).

Fifth, the team of social worker educators realised that raising consciousness of oppression and inequality is critical to amplify the voices of students and marginalised communities. Critical conscientisation is a process of increasing critical awareness of social reality through reflection and action (Freire, 1972) means that there should be ongoing engagement and dialogue about underlying causes of social problems. It is accepted that all human beings, if provided with the proper tools - can perceive their personal social, political, and economic contradictions and so act, as agents, on these oppressive conditions. Through critical conscientization, confidence develops to break the 'culture of silence' (Freire, 1972) enforced by dominant others, thus raising the voice of 'black' perspectives and challenging 'normalised realities' of 'white' privilege (Heleta, 2016).

Sixth, the team of educators were really conscious of the need to create space and opportunity for students to find and express 'Voice' so that they may be heard in everyday interactions and processes. The process of co-creating and subverting historical hierarchical knowledge production is an imperative of an education of Decoloniality. Accepting the 'no education is neutral' (Freire, 1972) the social work programme should facilitate critical conscientisation of students, through changed pedagogical practices and more conscious self-reflection on power hierarchies. Through encouraging the the voices of students as groups who are marginalized and oppressed, 'normalised' Colonialities can be disentangled and towards the achievement of Decoloniality.

Last and critically, the notion of Ubuntu, which places value on communitarianism and reciprocal altruism was identified as the seventh core principle for a decolonial social work curriculum. Ubuntu has been expressed in various ways in the African region and in different African languages, but in essence articulated that "I am because of who we all are" or "umntu, nguymntu, ngabantu" (Nyamnjoh, 2019), and it offers "hope and redemption, and offers a feasible framework for participatory and inclusive emancipatory social change" (p.1).

Mugumbate and Nyanguru, (2013, p. 84) cite Samkange and Samkange,(1980) who maintain that the maxims of ubuntu are that by recognising the humanity of the other, respectful relationships are established, that the preservation of life always takes precedence over personal gain and that at a political level, those in power owe their power and status to the will of those whom they rule over. It is also about humaneness, 'a pervasive spirit of caring and community, harmony and hospitality, respect and responsiveness that individuals and groups display for one another' (Mangaliso, 2001). It is clear therefore that there is a need to move from individualist notions in social work practice to the communalist concept of Ubuntu, that recognises the value of family and community

\section{CONCLUSION}

Work towards decoloniality is of necessity unsettling, disruptive and uncomfortable. The risk associated with work of this kind, as maintained by Patel Lisa, (2012) is that the process does achieve some change - enthusiastically reported on, embraced, and celebrated - but that due to the pervasive and structurally entrenched nature of Coloniality, structures of power asymmetries 
and privilege resume their effect and the work towards Decoloniality remains at the level of metaphor rather than reality.

Respecting Mamdani's (2011) maxim that for every experience, to have intellectual dignity, we have begun the process of theorisation, of a dialogical process of reflection, engagement and action towards Decoloniality of the social work programme (Freire, 1972). By theorising the process and outcomes, it becomes a way for those of us involved and those that follow, to be held to account, but also reflects an approach towards Decoloniality which contributes to knowledge production, shares experiences and develops local and contextual knowledge.

The process required a thinking of the various domains that needed to be engaged with in order to address Coloniality at various levels in the education system. The initial stages of this process, identified these seven domains, namely:- inclusion of theorists; pedagogical practices; educators themselves; learners; content; research and discourse; and the broader context. Through the process of interrogating these various domains of Decoloniality, seven principles were identified as critical to integrate throughout the social work education programme, at all levels and in all courses. These include- positioning Afrika as the centre; being alert to power dynamics; addressing structural issues, foregrounding race, class and gender; critical conscientisation and 'voice' and Ubuntu. Perhaps a different group and different process, would have led to a completely different set of domains and principles. However, the issues remains that this department has started a process of Decoloniality, that provides a basis for other educators, departments, schools, universities to consider addressing Decoloniality and contextualising the approach for their purposes.

It is nevertheless important to acknowledge that the process of working towards Decoloniality is not an easy task, it is fraught with challenge, opposition since it is disruptive and uncomfortable. Moreover, a achieving an attitude of Decoloniality and pursuing these changes is ongoing work, self- reflection, conscientisation and conscious effort and commitment. Audre Lorde's (1981, p.7) words so aptly describe this process and it's outcomes, "But anger expressed and translated into action in the service of our vision and our future is a liberating and strengthening act of clarification, for it is in the painful process of this translation that we identify who are our allies with whom we have grave differences, and who are our genuine enemies."

Nevertheless, there are a number of incitements that this process and its outcome have highlighted, and that provide impetus for the imperative to continue this work in practice and writing. Firstly, by avoiding the narrow interpretation of work towards Decoloniality relating to only curriculum change, those involved in the process of participatory action research for "Deep transformation towards Decoloniality in social work", experienced not only the intellectual, but also the discomforting emotional and liberatory engagement, through this process. These encounters unsettle the relationships and dynamics of power, privilege and previously silenced voices. Secondly, critical conscientisation cannot be undone. The realisation of the pernicious underlying structural causes of oppressions act as interpellation towards a belief that Decoloniality, freedom from oppression and inequality, and social change, is possible. Thirdly, the nature of ongoing Coloniality, racism, sexism, classism and inequality of the context, as well as the extent of the struggle for humanization within which social work education in South Africa occurs, forces an urgency for social change. Lastly, it is the students, who through their demands 
for \#Decolonisededucation \#Rhodesmustfall and \#Feesmustfall gave voice and impetus for change - perhaps that imperative cannot be undone and will continue to push educators and the system to ensure social, economic, and cultural justice. Time will tell.

\section{REFERENCE LIST}

Author 2008.

Author 2014.

Author and colleague 2018.

Alexander, M. J. (2006). Pedagogies of Crossing: Meditations on Feminism, Sexual Politics, Memory, and the Sacred. Durham: Duke University Press

Allie, R (2019). Honouring social workers on international social work day. Cape Argus, 19 March 2019, https://www.iol.co.za/capeargus/opinion/honouring-social-workers-on-internationalsocial-work-day-19968638

Bar-On, A (1999). Social Work and the 'Missionary Zeal to Whip the Heathen Along the Path of Righteousness' The British Journal of Social Work, 29(1), 5-

26, https://doi.org/10.1093/oxfordjournals.bjsw.a011440

Biko, S. 1987 [1978]. I Write What I Like Johannesburg: Heinemann

Bozalek, V. (2011). Acknowledging privilege through encounters with difference: Participatory Learning and Action techniques for decolonising methodologies in Southern contexts, International Journal of Social Research Methodology, 14(6), 469-484

Bulhan, H. A. 1980. Dynamics of cultural inbetweenity: An empirical study. International Journal of Psychology. 15(1-4):105-121

Césaire, Aimé. 2000 [1955]. Discourse on Colonialism. Monthly Review Press, New York.

Chilisa, B., Major, T.E., Khudu-Petersen, K. (2017). Community engagement with a postcolonial, African-based relational paradigm, Qualitative Research, 17(3,) 326-339

Comaroff, J. and Comaroff, J.L. (2015). Theory from the South: or, how Euro-America is evolving toward Africa. London: Routledge

Denzin, N. K. (2017). Critical Qualitative Inquiry. Qualitative Inquiry, 23 (1), 8-16.

https://doi.org/10.1177/1077800416681864

Department of Education, South Africa. 2008. Report of the Ministerial Committee on Transformation and Social Cohesion and the Elimination of Discrimination in Public Higher Education Institutions. Retrieved on 20 December 2017 from http://www.cepd.org.za/files/pictures/Report\%20of\%20the\%20Ministerial\%20Committee.pdf

Duncan, N 2003. 'Race' talk: discourse on 'race' and racial difference. Journal of Intercultural Relations. 27:135-156 
Duncan, N, Stevens, G, and Bowman, B. (2004). South African psychology and racism: Historical determinants and future prospects. In: Hook, D (Ed) 2004. Critical psychology. Landsdown: UCT Press.

Essed, P. (2002) 'Everyday Racism: a New Approach to the Study of Racism', in P. Essed and D.T. Goldberg (Eds) Race Critical Theories: Text and Context, pp. 176-94. Oxford: Blackwell Publishing.

Freire, P. 1972. Pedagogy of the oppressed (Translated by Myra Bergman Ramos). New York: The Seabury Press .

Fanon, F (1967). Black skin, white masks. New York: Grove Press

Foster, D. 2004. Liberation psychology. In: Hook, D (Ed) 2004. Introduction to critical psychology. Cape Town: UCT

Heleta, S. 2016. Decolonisation: Academics must change what they teach and how. The Conversation retrieved on 10 December 2018 from https://theconversation.com/decolonisationacademics-must-change-what-they-teach-and-how-68080

Hook, D (Ed) 2004. Introduction to critical psychology. Cape Town: UCT

Gray, M., Coates, J. 2010. '"Indigenization" and Knowledge Development: Extending the Debate', International Social Work 53 (5): 613-27

Grosfoguel, Ramón (2005) 'Subaltern Epistemologies, Decolonial Imaginaries and the Redefinition of Global Capitalism'. Review, vol. 28 , n.p .

Grosfoguel, R. 2013. The structure of knowledge in westernised universities: epistemic racism/sexism and the four genocides/epistemicides of the long 16th Century, Human Architecture: Journal of the Sociology of Self-Knowledge 11(1): 73-90

Heleta, S. (2016). Decolonisation of Higher Education: Dismantling Epistemic Violence and Eurocentrism in South Africa. Transformation in Higher Education, 1(1):1-8. Available at: https://thejournal.org.za/index.php/thejournal/article/view/9/21

Higher education South Africa (HESA) (2014) South African higher education in the 20th year of democracy: Context, achievements and key challenges, presentation to the Portfolio Committee on Higher Education and Training, Cape Town, 5 March http://pmg-assets.s3-website-eu-west1.amazonaws.com/140305hesa.pdf

Hochfeld, T. (2010) Social Development and Minimum Standards in Social Work Education in South Africa, Social Work Education, 29(4), 356-371, DOI: 10.1080/02615470903055463

hooks, b (1991). Yearning: Race, Gender and Cultural Politics. London: Turnaround Press. hooks, b. (2003). Teaching community: a pedagogy of hope. London: Routledge Lovesey, O. 2000. Ngũ gĩ wa Thiong'o. New York: Twayne Publishers, 2000.

Kaseke, E. (1991). Social work practice in Zimbabwe. Journal of Social Development in Africa, 6(1), 33-45 
http://pdfproc.lib.msu.edu/?file=/DMC/African\%20Journals/pdfs/social\%20development/vol6no1 Ljsda006001007.pdf

Keet, A., Sattarzadeh, S. D., \& Munene, A. 2017. An awkward, uneasy (de)coloniality higher education knowledge otherwise. Education as change, 21(1), 1-12

Kessi, S. 2013. Transforming previously white universities: Students and the politics of race representation. New Agenda: South African Journal of Social and Economic Policy, issue 50.

Kessi, S. \& Cornell, J. 2015. Coming to UCT: Black students, transformation, and discourses of race. Journal of Student Affairs in Africa. In press._Journal of Student Affairs in Africa | Volume 3(2) 2015, 1-16 | 2307-6267 http://jsaa.ac.za/index.php/jsaa/article/viewFile/1224/446

Kincheloe, J. L. and McLaren, P. (2000). Rethinking critical theory and qualitative research. In: Denzin, N. K. and Lincoln, Y.S. (2000). Handbook of qualitative research. California, Thousand Oaks: Sage ( $2^{\text {nd }}$ edition). London: Sage Publications (p. 279-313)

Kiguwa, P. 2014. Telling stories of race: $A$ study of racialised subjectivity in the post-apartheid academy. Unpublished PhD Thesis, University of the Witwatersrand, South Africa

Langa, M. (2017). \#Hashtag: An analysis of the \#FeesMustFall movement at South African Universities. Johannesburg: Centre for the Study of Violence and Reconciliation (CSVR).

Lourde (1981) Uses of Anger. KEYNOTE ADDRESS: THE NWSA CONVENTION. Women's studies Quarterly 9(3):7-10

Maldonado Torres (2007) On the coloniality of being: Contributions to the development of a concept. Cultural Studies 21(2), 240 - 270

Maldonado-Torres, M. 2017. Outline of Ten Theses on Coloniality and Decoloniality. Franz Fanon Foundation http://frantzfanonfoundation-fondationfrantzfanon.com/article2360.html

Mama, A 1995. Beyond the masks: Race, gender and subjectivity. London: Routledge

Mamdani, M. (2011) Africa's post-colonial scourge. Mail \& Guardian Getting Ahead, 27 May - 2 June Ministry of Education (2001) National Plan for Higher Education. Pretoria

Mmatli, T. (2008). Political activism as a social work strategy in Africa. International Social Work, 51(3), 297-310. https://doi.org/10.1177/0020872807083913

Mbembe, A. 2015. Decolonising knowledge and the question of the archive. Unpublished paper, WISER, University of the Witwatersrand http://wiser.wits.ac.za/system/files/Achille\%20Mbembe\%20\%20Decolonizing\%20Knowledge\%20and\%20the\%20Question\%20of\%20the\%20Archive.pdf

Mignolo, W. D. (2007). Introduction: Coloniality of power and decolonial thinking. Cultural Studies, 21(2-3)155-167, DOI: 10.1080/09502380601162498, 155-167, DOI: $10.1080 / 09502380601162498$. 
Mirza, H. S. (2018). Decolonizing Higher Education: Black Feminism and the Intersectionality of Race and Gender. Journal of Feminist Scholarship 7 (Fall), 1-12

https://digitalcommons.uri.edu/jfs/vol7/iss7/ 3

Modiri, J. 2016. In the Fall: Decolonisation and the rejuvenation of the academic project in South Africa. Daily Maverick. Retrieved on 2 December from

https://www.dailymaverick.co.za/opinionista/2016-10-16-in-the-fall-decolonisation-and-therejuvenation-of-the-academic-project-in-south-africa/\#.Wkjux99I-M9

Mupediswa, R. (1992). Africa at the crossroads: Major challenges for social work education and practice towards the year 2000. Journal of Social Development in Africa, 7(2), 19-38

Mugumbate, J. \& Nyanguru, A. (2013). Exploring African philosophy: the value of ubuntu in social work, African Journal of Social Work, 3(1), 82-100

Ndlovu-Gatsheni, S. (2018). Dynamics of epistemological decolonisation in the $21^{\text {st }}$ century: Towards epistemic freedom. Strategic Review for Southern Africa, Vol 40, No 1 pp. 16-45 Accessed 2 December 2018 from https://www.up.ac.za/media/shared/85/Strategic\%20Review/vol\%2040(1)/Ndlovu-Gatsheni.pdf

Nyamnjoh, F. (2019). Ubuntuism and Africa: Actualised, Misappropriated, Endangered and Reappraised, Africa Day Memorial Lecture Auditorium, Equitas Building, University of the Free State, Bloemfontein Wednesday 22 May 2019 at 17:30

https://www.researchgate.net/publication/333323780 Nyamnjoh Ubuntuism Lecture 20192105 Final Version

Osei-Hwedi, K (1993). The Challenge of Social Work in Africa: Starting the Indigenisation Process, Journal of Social Development in Africa, 8(1), 19-30

Osei-Hwedie, K. (1996) 'The Indigenization of Social Work Education and Practice in South Africa: The Dilemma of Theory and Method', Social Work/Maatskaplike Werk 32(3): 215-25.

Patel. Lisa (Leigh) (2014). Countering Coloniality in Educational Research: From Ownership to Answerability, Educational Studies, 50(4), 357-377, DOI: 10.1080/00131946.2014.924942

Quijano, A. (2000). Coloniality of Power, Eurocentrism, and Latin America Nepantla: Views from South 1.3 Copyright 2000 by Duke University Press,

http://citeseerx.ist.psu.edu/viewdoc/download?doi=10.1.1.483.5399\&rep=rep1\&type =pdf

Quijano, A. (2007). Coloniality and modernity/rationality. Cultural Studies 21(2-3), 168-178, https://doi.org/10.1080/09502380601164353.

wa Thiongo, N. 1986. Decolonising the mind: the politics of language in African literature. Heinemann Educational, 1986

Reisch, M. and Janie, J.S. (2012). The New Politics of Social Work Practice: Understanding Context to Promote Change, British Journal of Social Work 1-19 doi:10.1093/bjsw/bcs072

Rivkin, J and Ryan, M. 2004. Literary theory: An anthology. Blackwell Publishing pp1126-1150 
Rohleder, P., Swartz, L., Bozalek, V., Carolissen, R. \& Leibowitz, B. (2008) Community, self and identity: participatory action research and the creation of a virtual community across two South African universities, Teaching in Higher Education, 13:2, 131-

143, DOI: $10.1080 / 13562510801923187$

Romm, N. R. A. (2015). Conducting Focus Groups in Terms of an Appreciation of Indigenous Ways of Knowing: Some Examples from South Africa forum: qualitative social research sozialforschung, 16(1), Art. 2, http://nbn-resolving.de/urn:nbn:de:0114-fqs150120

Ross, E. (2008). The intersection of cultural practices and ethics in a rights-based society: Implications for South African social workers. International Social Work, 51(3), 384395. https://doi.org/10.1177/0020872807088084

Sakamoto and Pitner (2005). Use of critical consciousness in anti-oppressive social work practice: disentangling power dynamics at personal and structural levels. British Journal of Social Work. $35,435-452$

Sewpaul, V. (2007) 'Power, Discourse and Ideology: Challenging Essentialist Notions of Race and Identity in Institutions of Higher Learning in South Africa', Social Work/Maatskaplike Werk 43(1): 16-27. Google Scholar

Spivak, G. 1988. Can the Subaltern Speak? In: Nelson, C. and Grossberg, L. (eds) Marxism and the interpretation of culture, MacMillan Education: Basingstoke. pp. 271-313

Statistics South Africa (2018) Poverty on the rise in South Africa.

http://www.statssa.gov.za/?p=10334

Stevens, G. 2003. Academic representations of 'race' and racism in psychology: Knowledge production, historical context and dialectics in transitional South Africa. International Journal of Intercultural Relations 27

Trafford, J. (2019). EMPIRE'S NEW CLOTHES. Angelaki, 24(1), 37-54, DOI:

10.1080/0969725X.2019.1568732.

Trowler, V. (2018) Book review: Jansen, J. (2017). As By Fire: The End of the South African University. Pretoria, South Africa: Tafelberg. Journal of Student Affairs in Africa 6(2), 131-136 DOI: $10.24085 /$ jsaa.v6i2.3316

Tuck, E \& Yang, K.W. (2012) Decolonization is not a metaphor. Decolonization: Indigeneity, Education \& Society 1(1), 1-40

Vazquez, R. (2015) Decolonial practices of learning. In: John Friedman Vicki Haverkate Barbara Oomen Eri Park Marcin Sklad Going glocal in higher education: the theory, teaching and measurement of global citizenship, University College Rooseveldt, 92-100

World Bank (2018). Overcoming Poverty and Inequality in South Africa : An Assessment of Drivers, Constraints and Opportunities, http://documents.worldbank.org/curated/en/530481521735906534/Overcoming-Poverty-andInequality-in-South-Africa-An-Assessment-of-Drivers-Constraints-and-Opportunities 
World Economic Forum (2019). South Africa's economy in five charts.

https://www.weforum.org/agenda/2019/05/south-africas-economy-in-5-charts/

\section{AUTHOR BIOGRAPHIES}

Dr Linda Harms Smith joined Robert Gordon University, Aberdeen, Scotland in 2015 after working at the University of the Witwatersrand, Johannesburg for 15 years, where she obtained her PhD on 'Critical imperatives for social change in social work education'. Her research interests include Social Work knowledge and ideology; Decoloniality; Critical social work; and Collective trauma. She has received research grants and awards from the SA National Research Foundation; Carnegie Foundation; Oppenheimer Trust; and Anderson Capelli Trust. Her social work experience includes community development and work with children and families. She has played an active role in Association of South African Social Work Education Institutions (Deputy President for two years); University structures for Transformation; Student Wellbeing; Teaching and Learning; and Research. Her commitment to critical and radical social work developed from within the context of the oppressive and post-colonial South African Apartheid system. She is a member of SWAN (Social Work Action Network) Steering Committee in the UK, and is a member of the Editorial Boards of Critical and Radical Social Work and International Social Work Journals.

Prof Shahana Rasool is currently the Head of Department of Social Work at the University of Johannesburg. As a Rhodes Scholar she obtained her D Phil. in Social Work and Social Policy from the University of Oxford, UK. Her research interests are within the field of gender, genderbased violence, adolescent gender attitudes, adolescent experiences and witnessing gender based violence, feminism, as well as decoloniality and transformation. She served on several committees such as the University HIV committee and the faculty higher degrees committee. She has 20 years of social work experience including training, research and lecturing. Shahana has received numerous awards and grants: including the Rhodes Scholarship; Abe Bailey Travel Scholarship; Ernest Oppenheimer Scholarship, and funding from the South African National Research Foundation. She is the chair of the board for The Southern African Journal of Social Work and Social Development and sits on the board of the Journal of International Women's Studies. 